Special Issue

\title{
The Rescue of Jews in France and its EMPIRE DURING WORLD WAR II History and Memory
}

Guest Editor: Vicki Caron, Cornell University*

Introduction

Robert O. Paxton

Columbia University

Shanny L. Peer

Columbia University

Amidst so many works devoted to the Shoah, the rescue of Jews is a relatively neglected subject. This is especially so in the case of France, for reasons explored by Renée Poznanski in her introductory essay to this special issue. The papers published here were presented at a conference on the rescue of Jews in France and the French Empire during World War II, held at the Maison Française of Columbia University on 24-25 March 2011. ${ }^{1}$

\section{Jews, Foreigners, and Antisemitism in 1930s France}

The antisemitism that found its deadliest expression in World War II was not a new phenomenon in France, of course, though it had diminished markedly during the First World War and into the 1920s. Between the two world wars France admitted more Jewish refugees, proportionally, than the United States. By 1939,7 percent of the French population was foreign-born, and included at least 150,000 foreign Jews, of whom some 60,000 were recently arrived refugees from central and eastern Europe. ${ }^{2}$ 
The presence of a large Jewish refugee population exacerbated three deep French anxieties in the 1930s. First, during the Great Depression, many French people perceived foreign immigrants as competing with them for scarce jobs. Second, many feared that this large foreign presence, which seemed to be slow or reluctant to assimilate, was diluting a French civilization already under threat on several fronts-especially from socialism and communism, which were perceived as essentially Jewish. Third, some French feared that Jewish immigrants were working to push France into a war against the Jews' main enemy, Adolph Hitler. This perception of a link between the threat of war and Jewish influence in France was sharpened by the election of the Popular Front in May-June 1936 and the designation of Léon Blum as the first socialist and first Jewish prime minister in French history. Overt expressions of antisemitism surged again by the late 1930s in France, even by prominent and widely respected writers such as Jean Giraudoux and Marcel Jouhandeau. Add to this mix the search for scapegoats after the shocking defeat of May-June 1940, and one begins to understand the Vichy assault on Jews, foreigners, and partisans of the Popular Front. ${ }^{3}$

\section{Seventy-Five Percent of Jews Survive in France}

After the defeat, the traditional French defenders of Jews were out of power. But they still existed in the population. Many French people put themselves at risk by hiding or otherwise protecting Jews, especially after the dangers to Jews escalated dramatically in 1942. One entryway into this subject is the Dictionnaire des Justes de France, the list of all those certified by the Yad Vashem Holocaust Martyrs' and Heroes' Remembrance Authority in Jerusalem as having protected Jews in wartime France despite personal risk. ${ }^{4}$ The Dictionnaire lists more than 3,200 names. But there were certainly many times more rescuers in France than that. Many rescuers modestly or prudently declined to be memorialized. In other cases the victims disappeared, leaving no one to testify about helpers along the way. Still others simply kept secrets.

Some have argued that a broader measure of the magnitude of Jewish rescue is the large number of Jews who survived in France. About 25 percent of the approximately 320,000 Jews living in France in 1940 (the largest Jewish population in Western Europe) were killed: about 76,000 were deported to their deaths and another 3,000 died of hunger or disease in French camps. ${ }^{5}$ But 75 percent survived. What does this survival rate tell us?

Defenders of Vichy have subscribed to the claim first made by Xavier Vallat, Vichy's first Commissioner of Jewish Affairs, who maintained in his 1947 trial that the survival rate reflected Vichy's efforts to save Jews of French nationality. ${ }^{6}$ Vichy apologists have commonly resorted to comparisons, claiming that things were evidently better for Jews in France than in Holland (where only 27 percent survived) or Belgium (where 60 percent survived). But these 
are not appropriate countries for comparison, since they were totally occupied and offered far fewer remote areas for concealment than France did. More appropriate comparisons would be unoccupied or partially occupied countries with their own governments like Italy (83 percent of Jews survived), Denmark (99.2 percent survived) or Bulgaria (nearly 100 percent survived). ${ }^{7}$

In more recent years, mainstream French political leaders including President Jacques Chirac have appropriated Yad Vashem's term "Righteous Among the Nations" in order to highlight the "Righteous of France," who, Chirac asserted, "saved 75 percent of the Jews of France." In a ceremony on 18 January 2007, Chirac placed "les Justes de France" symbolically in the Pantheon. Sarah Gensburger's essay on the politics of this memory documents the attempt to counterbalance the acts of the Vichy regime, whose role in abetting the deportations Chirac acknowledged in a historic speech on 16 July 1995, with the heroic rescue efforts of countless "anonymous" French men and women. "Thanks to them," Chirac said, "we can be proud to be French."

In fact, the raw numbers of Jewish survivors tell us very little by themselves. To comprehend the rescue of Jews in France one must examine individual stories in detail, as some of the papers and debates in this conference do. Each act of rescue was unique to some exent, although of course there were patterns. Networks, organizations, and orchestrated rescue efforts-such as the one led by New Yorker Varian Fry, featured in the documentary previewed by Pierre Sauvage at our conference-also provided keys to survival. ${ }^{8}$ The best current research examines what occurred at the local or even individual level. ${ }^{9}$ Only there can one begin to weigh the various factors that led to escape or death: geography, the efficiency and zeal of the local police, the sympathy of the population, networks and social service organizations, and-perhaps the most influential factor-the level of Nazi effort.

\section{Jews in France Face Double Jeopardy}

The situation of Jews living in wartime France was complicated by the existence of a quasi-independent French government at Vichy, responsible for an unoccupied zone, that made France unique in Nazi-dominated Europe. What difference did this special situation make? Here we return to the question raised above: Did the Vichy government in fact aid Jews in any way, or were its actions altogether harmful? On the negative side stands Vichy's autonomous anti-Jewish project that reached a high point with the Jewish statute of 3 October 1940 excluding Jews from government employment and the cultural professions. It was adopted independently of German pressure. Indeed, at that early date, the Nazis did not want to empty France of its Jewish population. Rather, they wished to use France as a dumping ground for German Jews. In October 1940, at the very moment when Marshal Philippe Pétain was shaking Hitler's hand at Montoire-sur-le-Loir, the Nazi gauleiters of 
the Rhineland loaded 6,500 German Jews at very short notice onto trains and expelled them into the unoccupied zone of France. Evolving German policy settled on extermination only at the end of 1941, and this stage was applied to France starting in spring $1942 .{ }^{10}$

Vichy's own anti-Jewish measures, even if less murderous than those of the Nazis, dovetailed nicely with Hitler's plans, and made it easier to deport Jews to death camps once mass exterminations began in 1942. Vichy's police force, meticulous card files of Jewish names and addresses compiled by bureaucrats under Vichy (in the occupied zone these were compiled by the French police), and concentration camps were essential cogs in the deportation mechanism that would send Jews from France to their death in the east. Loss of jobs and property (Vichy began confiscating Jewish property in 1941) made Jews even more vulnerable to the eventual Nazi manhunts. Jews in France faced not just one official antisemitism backed by the forces of a state but two.

The most notable Vichy contribution to the Nazi extermination project was the delivery in the summer of 1942 of 10,417 foreign Jews, including women and children, from camps in the unoccupied zone to Nazi authorities in the occupied zone. ${ }^{11}$ No other western European country handed over Jews from areas not occupied by German troops, and there were only three such cases in eastern Europe. ${ }^{12}$

So things were worse for Jews in France than they would have been without Vichy. It is of course true that some Vichy officials helped Jews, but they did so personally and in defiance of their government. It is also true that the Vichy government began to drag its feet when the mass deportations began. In May 1942 Vichy refused to follow the Nazis in requiring Jews in the unoccupied zone to wear a yellow star; indeed, in March 1942 Vallat was forced out of office over his criticism of this German proposal, among other reasons. ${ }^{13}$ Vichy officials also tried to limit the deportations to foreign Jews, although they knew full well that this was only a temporary delay (the Germans deported foreign Jews first in Belgium also, of their own volition, there being no Belgian state to placate, so Vichy supporters cannot claim that Vichy won this policy as a special concession). Vichy also refused in 1943 the Nazi request to denationalize all Jews who had acquired French nationality since 1927. But these delaying measures came too late, after much of the damage had already been done. The Vichy government never tried actively to block the deportations as Hungary and Bulgaria did with respect to their own Jewish nationals.

\section{Who Were the Rescuers?}

Who then were the rescuers? One is struck by their variety. The "Righteous Among the Nations" recognized by Yad Vashem even included some ardent Pétainistes like Bishop Paul Rémond of Nice, a key figure in Miranda Pollard's 
essay. No single factor provided a magic key that could predict how a person would react when a hunted family knocked at the door.

This conference innovated in several respects. It explored how some rescuers have been selected for official recognition in Israel and France, and the politics of memory that have shaped these choices. This topic is addressed most directly here by Mordecai Paldiel and Sarah Gensburger, but the question of who gets recognized and why was a recurring theme throughout the conference. This conference also went beyond the official definition of "Righteous Gentiles" to include Jewish rescuers (not memorialized at Yad Vashem) such as Rabbi Zalman Schneerson (discussed by Harriet Jackson), Andrée Salomon (discussed by Georges Weill), and Joseph Bass (discussed by Susan Zuccotti and Harriet Jackson), as well as some Arab rescuers in North Africa (discussed by Robert Satloff), ${ }^{14}$ and to ask why these rescuers have not been adequately recognized. Indeed, a major theme of this conference was that rescue would not have been achieved without extensive cooperation between Jewish and nonJewish organizations, which in the metropole were overwhelmingly Christian.

The conference also extended its scope beyond metropolitan France to include the French Empire. If Jews in France had been exposed only to the Nazi threat, we would not need to study French colonies far from German occupation. But Vichy applied its anti-Jewish discrimination and exclusionary policies rigorously to overseas territories. ${ }^{15}$ Eric Jennings' essay in this volume discusses the escape route taken by hundreds of Jews through Marseille to Martinique and asks whether endorsement of this route by Vichy officials amounted to humanitarian rescue or expulsion. He also reflects on the impact of this enforced tropical stay on the intellectual and cultural productivity of refugees such as Victor Serge, André Breton, Anna Seghers, Claude Lévi-Strauss, and Germaine Krull. ${ }^{16}$ Robert Satloff also touched on the colonial experience when he discussed Arab rescuers in North Africa, as depicted in his book, Among the Righteous. ${ }^{17}$

The French author Serge Doubrovsky once summed it up well: those Jews who died were victims of the Vichy regime's actions; those who were saved frequently owed their lives to the actions of individual French men and women. These individuals included Jews, Christians, and in some cases even Muslims. Their courageous and benevolent actions are the subject of the following pages.

* Vicki Caron is the Thomas and Diann Mann Professor of Modern Jewish Studies at Cornell University. Her major publications include: Between France and Germany: The Jews of Alsace-Lorraine, 1871-1918 (1988); Uneasy Asylum: France and the Jewish Refugee Crisis, 1933-1942 (1999; pb. edition, 2001; French trans.: L'Asile incertain: Les réfugiés juifs en France, 1933-1942 [2008]). Her current project is titled: The Battle for the Republic: Jewish-Catholic Relations in France, 1870-1914 (forthcoming, Harvard University Press), which is the first of an anticipated two-volume work on Jewish Catholic Relations in France since 1870 . 
Robert Paxton is professor emeritus of Modern European History at Columbia University. He specializes in the history of Europe in the twentieth century, with particular emphasis on fascism and on France during the German occupation. Among his works are Parades and Politics at Vichy (1966), Vichy France: Old Guard and New Order (1972, new ed. 2001), Vichy France and the Jews (with Michael Marrus) (1981), French Peasant Fascism (1997), and The Anatomy of Fascism (2004). His Twentieth Century Europe, now with Julie Hessler, is in its 5th edition (2011).

Shanny Peer holds a Ph.D. from NYU's Institute of French Studies. She taught French studies for ten years, at the University of Vermont and NYU. Her publications include France on Display: Peasants, Provincials, and Folklore in the 1937 Paris World's Fair, which argued that France's "traditional" heritage was refashioned in and around the 1937 World's Fair to allow France to modernize while retaining its distinct identity in the key decade before WWII. France on Display won the Laurence Wylie Prize for Best Book in French Cultural Studies in 1999. From 2000 to 2007, Peer was Director of Policy Programs at the French-American Foundation. Since 2009 she has been Director of the Columbia Maison Française.

\section{Notes}

1. We gratefully acknowledge the Florence Gould Foundation, the Maurice I. Parisier Foundation, Mrs. Henriette Beilis, and the Executive Vice President of Arts and Sciences at Columbia for the support they provided for this conference and publication. We also thank Harriet Jackson for suggesting the idea for this conference and playing a key role as conference organizer, and we thank Herrick Chapman, editor of French Politics, Culture \& Society, and Vicki Caron, guest editor of this special volume, for their care and skill in preparing the conference papers for publication.

2. No exact number is available, for French civic documents make no reference to racial or ethnic identity. However, it is generally estimated that there were approximately 300,000 Jews in France on the eve of World War II, and over half of these were foreign born. See Paula E. Hyman, The Jews of Modern France (Berkeley, CA: University of California Press, 1998), 137. On the number of refugees on the eve of the war, see Vicki Caron, Uneasy Asylum: France and the Jewish Refugee Crisis, 1933-1942 (Stanford, CA: Stanford University Press, 1999), 305.

3. Michael R. Marrus and Robert O. Paxton, Vichy France and the Jews (New York: Basic Books, 1981), 25-71; Caron, Uneasy Asylum; Caron, "The 'Jewish Question' from Dreyfus to Vichy," in French History since Napoleon, ed. Martin S. Alexander (London: Arnold, 1999), 172-202. 
4. Dictionnaire des Justes de France, ed. Lucien Lazare (Jerusalem: Yad Vashem and Paris: Fayard, 2003). See also the essays by Mordecai Paldiel and Sarah Gensburger in this volume.

5. Serge Klarsfeld, Le Calendrier de la persécution des Juifs en France (Paris: Les Fils et Filles de Deportés Juifs de France, 1993), 1091.

6. Le Procès de Xavier Vallat, présenté par ses amis (Paris: Éditions du Conquistador, 1948), 118.

7. See Michael R. Marrus and Robert O. Paxton, "The Nazis and the Jews in Occupied Western Europe, 1940-1944," in Unanswered Questions: Nazi Germany and the Genocide of the Jews, ed. François Furet (New York: Schocken Books, 1989), 172-98 (also in The Journal of Modern History 54, 4 [December 1982]: 687-714).

8. Pierre Sauvage, dir., And Crown Thy Good: Varian Fry in Marseille (Varian Fry Institute, Chambon Foundation), forthcoming feature documentary, 2013.

9. An outstanding article that seeks to identify the crucial variable for survival in the Netherlands by differential analysis of neighborhoods is Marnix Croes, "The Holocaust in the Netherlands and the Rate of Jewish Survival," Holocaust and Genocide Studies 20, 3 (Winter 2008): 474-99. See also the case-by-case study of the 991 Jews of Lens (Pas-de-Calais) in Nicolas Mariot and Claire Zalc, Face à la persécution: 991 Juifs dans la guerre (Paris: Odile Jacob, 2010); and Shannon Fogg, The Politics of Everyday Life in Vichy France: Foreigners, Undesirables and Strangers (New York: Cambridge University Press, 2009). Fogg's study focuses on public opinion in the Limousin-which includes the departments of the Creuse and the Haute Vienne.

10. Marrus and Paxton, Vichy France and the Jews.

11. Klarsfeld, Le Calendrier de la persécution des Juifs en France, 1114.

12. Hungary turned over to the Germans Jews taken prisoner in areas conquered from the Soviet Union in 1941; Romania did the same, in addition to conducting its own pogrom; Bulgaria, which protected its own national Jewish population, transferred Jews captured in occupied Macedonia and Thrace to the Germans. See Bela Vago, "The Reaction to the Nazi Anti-Jewish Policy in East-Central Europe and in the Balkans," in Unanswered Questions, ed. Furet, 199-34; Marrus and Paxton, Vichy France and the Jews, 356-72.

13. Ibid., 118.

14. Satloff's paper, "Arab Rescuers of Jews in Vichy North Africa: Their Role and Relevance," could not be included in this issue. But see Robert Satloff, Among the Righteous: Lost Stories from the Holocaust's Long Reach into Arab Lands (Cambridge, MA: Public Affairs ${ }^{\mathrm{TM}}$, 2006).

15. Eric Jennings, Vichy in the Tropics (Stanford, CA: Stanford University Press, 2001).

16. See Jennings, "Last Exit from Vichy France: The Martinique Escape Route and the Ambiguities of Emigration, 1940-1941," The Journal of Modern History 74 (June 2002): 289-324.

17. Satloff, Among the Righteous. 